\title{
Efektivitas Terapi Aktivitas Kelompok Model Interpersonal Dan Model Psikodrama Terhadap Perubahan Tingkat Depresi Lansia: Studi Kasus Di Panti Sosial Tresna Werdha Mataram
}

\author{
Vera yulandasari $i^{1 *}$ \\ Email: vera.yulandasari15@gmail.com \\ 1) Keperawatan Universitas Qamarul Huda Badaruddin
}

\begin{abstract}
ABSTRAK
Depresi adalah salah satu masalah psikologis yang dialami oleh lansia. Lingkungan tempat tinggal sebagai salah satu faktor penyebab depresi dapat menyebabkan masalah kejiwaan maupun fisik. Ada beberapa terapi yang dapat digunakan untuk mengurangi depresi pada lansia salah yaitu dengan metode terapi aktivitas kelompok model interpersonal dan terapi aktivitas kelompok model psikodrama. Penelitian menggunakan desain Quasy Exsperiment (Two-Group Pre - Post Test Design). Populasi penelitian adalah semua lansia yang mengalami depresi yang berada di Panti Sosial Tresna Werdha Mataram dan tekhnik sampling yang digunakan adalah purposive random sampling. Uji statistik yang digunakan adalah "Mann Whitney Test" untuk mengetahui pengaruh terapi aktivitas kelompok terhadap tingkat perubahan depresi. Hasil penelitian menunjukkan tidak ada hubungan yang signifikan antara terapi aktivitas kelompok model Interpersonal dengan perubahan tingkat depresi dengan nilai $\mathrm{p}=0,085$, sedangkan ada hubungan yang signifikan antara pemberian TAK Psikodrama dengan perubahan tingkat depresi pada lansia dengan nilai $p=0,005$. jadi dari kedua terapi aktivitas kelompok model interpersonal dan model psikodrama, didaptkan bahwa terapi aktivitas kelompok model psikodrama yang lebih efektif terhadap perubahan tingkat depresi pada lansia.
\end{abstract}

Kata kunci: Terapi aktivitas kelompok, Interpersonal, Psikodrama, Depresi lansia

\begin{abstract}
Depression is one of the psychological problems experienced by the elderly. The environment of residence as one of the factors causing depression caused psychological and physical problems. There are several therapies that can be used to reduce depression in the elderly by interpersonal model activity therapy and psychodrama model group activity therapy. The study uses the Quasy Exsperiment design (Two-Group Pre-Post Test Design). The study population was all elderly who were depressed at the Tresna Werdha Mataram Social Institution and the sampling technique used purposive random sampling. The statistical test used "Mann Whitney Test" to determine the effect of group activity therapy on the level of change in depression. The results showed that there was no significant relationship between the therapy of Interpersonal model group activity with changes in depression levels with $p=0,085$, while there was a significant relationship between Psychodrama and changes in depression levels in the elderly with $\mathrm{p}=0,005$. So, from both the interpersonal model and psychodrama model group activity therapy, it was found that group activity therapy in the psychodrama model was more effective in changing depression levels in the elderly.
\end{abstract}

Keywords: Group activity therapy, Interpersonal, Psychodrama, Elderly's depression. 


\section{A. LATAR BELAKANG}

Depresi merupakan salah satu masalah kesehatan mental utama saat ini, yang mendapat perhatian serius. Di negara-negara berkembang WHO memprediksi depresi akan menjadi salah satu penyakit mental yang banyak dialami dan depresi berat akan menjadi kedua terbesar kematian setelah serangan jantung. Pada masa sekarang ini depresi menjadi jenis gangguan kejiwaan yang paling sering dialami oleh masyarakat karena tingkat stres yang sangat tinggi akibat tuntutan hidup yang semakin bertambah[1].

Gangguan depresi sering di mulai dari masa kanak-kanak sampai lanjut usia[2]. Sedangkan depresi dan masalah trauma psikis adalah masalah jiwa (psikologis) yang paling menonjol pada lansia[3]. Dimana lansia laki-laki memiliki angka kejadian 5\% dan lansia perempuan sedikit lebih tinggi yaitu $7 \%$ akan tetapi depresi pada lansia dapat mengakibatkan efek yang lebih berat[2].

Dari beberapa faktor penyebab terjadinya depresi pada lansia adalah lingkungan tempat tinggal sehingga secara tidak langsung dapat mengakibatkan perubahan peran dalam menyesuaikan diri akan mengalami masalah serius khususnya pada masalah kejiwaan maupun fisik[4]. Depresi pada lansia juga dapat terjadi karena lansia banyak mengalami stressor. Karena adanya musibah psikososial seperti kemiskinan, isolasi sosial, dan lain-lain akan meningkatkan kerentaan untuk mengalami depresi atau sebagai faktor pencetus[5].

Ada beberapa terapi yang mampu mengurangi depresi pada lansia, salah satunya dengan menggunakan terapi aktivitas kelompok. Terapi aktivitas kelompok merupakan terapi modalitas terapi keperawatan untuk lansia dalam bentuk permainan, atau interaksi satu dengan yang lain. Terapi Aktivitas Kelompok juga dapat melatih lansia untuk mempersepsikan stimulus yang pernah di alami [4]. Terapi Aktivitas Kelompok mempunyai manfaat terapeutik umum yaitu meningkatkan uji realitas melalui komunikasi dan umpan balik dengan atau dari orang lain, melalui sosialisasi dan membangkitkan sosialisasi untuk kemajuan fungsi kognitif dan afektif [6]

Menurut Purwaningsih [7], kerangka teoritis terapi aktifitas kelompok terbagi menjadi 4 yaitu, model fokal konflik, model komunikasi, model interpersonal dan model psikodrama. Model interpersonal dan model psikodrama adalah bentuk aktif dari kelompok psikoterapi dimana model interpersonal mengajarkan anggota kelompoknya untuk belajar berinteraksi dan dapat mengidentifikasi kesalahan dari persepsi dan perilaku sosial, sedangkan melalui terapi aktivitas kelompok model psikodrama akan menggali emosional dengan metode dramatik yang akan di ingatkan kembali dengan pengalaman masa lalunya[8].

Melalui terapi aktivitas kelompok model interpersonal dan terapi aktivitas model psikodrama, peneliti ingin membandingkan efektivitas kedua model terapi aktivitas kelompok yang lebih berpengaruh untuk perubahan tingkat depresi pada lansia.

\section{B. METODE PENELITIAN}

Desain penelitian merupakan hasil akhir dari suatu tahap keputusan yang dibuat oleh peneliti berhubungan dengan bagaimana penelitian bisa diterapkan[10]. Dalam penelitian ini peneliti menggunakan desain Quasy Exsperiment (TwoGroup Pre - Post Test Design). Populasi semua lansia yang mengalami depresi yang berada di Panti Sosial Tresna Werdha Mataram, peneliti akan mengambil 10 orang sampel untuk TAK model Psikodrama dan 10 orang untuk TAK model Interpersonal dengan tekhnik sampling yang digunakan adalah purposive random sampling. tabulasi data dengan menggunakan uji statistik "Mann Whitney Test" untuk mengetahui pengaruh variabel independen terhadap variabel dependen.

\section{HASIL DAN PEMBAHASAN}

\section{Hasil}

Hasil penelitian ini ditampilkan dalam bentuk analisa univariat yang digunakan untuk 
menganalisis variabel-variabel yang ada secara deskriptif serta analisa bivariat yang digunakan untuk mengetahui Efektivitas Terapi Aktivitas Kelompok Model Interpersonal Dan Model Psikodrama Terhadap Tingkat Depresi Lansia.

\section{Tabel 1. Perbedaan efektivitas terapi aktivitas kelompok model interpersonal dan model psikodrama terhadap perubahan tingkat depresi lansia.}

\begin{tabular}{|c|c|c|c|c|}
\hline \multirow{2}{*}{$\begin{array}{c}\text { Tingkat } \\
\text { Depresi }\end{array}$} & \multicolumn{2}{|c|}{ TAK } & \multicolumn{2}{c|}{ TAK } \\
\cline { 2 - 5 } & $\begin{array}{c}\text { Interpersonal } \\
\text { test }\end{array}$ & $\begin{array}{c}\text { Post } \\
\text { test }\end{array}$ & $\begin{array}{c}\text { Pre } \\
\text { test }\end{array}$ & $\begin{array}{c}\text { Post } \\
\text { test }\end{array}$ \\
\hline $\begin{array}{c}\text { Depresi } \\
\text { Minimal }\end{array}$ & 0 & 1 & 0 & 3 \\
\hline $\begin{array}{c}\text { Depresi } \\
\text { Ringan }\end{array}$ & 5 & 7 & 3 & 6 \\
\hline $\begin{array}{c}\text { Depresi } \\
\text { Sedang }\end{array}$ & 5 & 2 & 7 & 1 \\
\hline $\begin{array}{c}\text { Depresi } \\
\text { Berat }\end{array}$ & 0 & 0 & 0 & 0 \\
\hline Total & 10 & 10 & 10 & 10 \\
\hline P Value & \multicolumn{2}{|c|}{0,085} & \multicolumn{2}{c|}{0,005} \\
\hline
\end{tabular}

Berdasarkan Tabel 1 menunjukkan bahwa dari 10 orang responden Terapi Aktifitas Kelompok (TAK) Model Interpersonal, sebelum pemberian TAK, 5 orang (50\%) mengalami depresi ringan dan 5 orang lagi mengalami depresi sedang (50\%) berubah menjadi 1 orang responden (10\%) mengalami depresi minimal, 7 orang responden $(70 \%)$ mengalami depresi ringan, 2 orang responden (20\%) mengalami depresi sedang dan tidak ada yang mengalami depresi berat setelah pemberian TAK Interpersonal dengan nilai kemaknaan 0,085 yang berarti tidak ada hubungan yang signifikan antara TAK Interpersonal dengan perubahan tingkat depresi. Untuk Terapi Aktifitas Kelompok (TAK) Model Psikodrama, dari 10 orang responden sebelum pemberian terapi, 3 orang $(30 \%)$ mengalami depresi ringan, 7 orang (70\%) mengalami depresi sedang. Dan setelah pemberian TAK Psikodrama terjadi perubahan tingkat depresi pada responden menjadi 3 orang (30\%) depresi minimal, 6 orang $(60 \%)$ depresi ringan dan 1 orang (10\%) mengalami depresi sedang, sedangkan tidak ada responden yang mengalami depresi berat dengan tingkat kemaknaan $\mathrm{p}=0,005$ artinya ada hubungan yang signifikan antara pemberian TAK Psikodrama dengan perubahan tingkat depresi pada responden.

\section{Pembahasan}

Pengukuran efektivitas masing-masing Terapi Aktifitas Kelompok baik Model Interpersonal maupun Model Psikodrama di dasarkan pada besarnya perubahan perilaku yang terjadi setelah mendapatkan perlakuan. Dalam hal ini peneliti menggunakan hasil uji statistik dan nilai signifikansi sebagai dasar menentukan besar atau kecilnya perubahan perilaku yang terjadi setelah pemberian perlakuan. Semakin kecil nilai signifikansi maka perubahan yang terjadi akibat perlakuan semakin besar dan nilai keefektitasannya semakin tinggi.

Dari hasil uji statistik didapatkan nilai signifikansi untuk TAK Model Interpersonal adalah $\mathrm{p}=0,085$. Hal ni berarti tidak ada perubahan yang signifikan pada responden yang mendapatkan TAK Model Interpersonal. Dalam hal ini perubahan tingkat depresi responden akibat TAK Model Interpersonal tetap ada walaupun sedikit. Ini berarti bahwa keefektivan TAK model Interpersonal di Panti Sosial Tresna Werdha Panti Sosial Tresna Werdha Mataram masih kurang dalam perubahan tingkat depresi lansia. Hal ini bertentangan dengan dengan hasil penelitian yang dilakukan oleh Yudi Kurniawan [9] yang menyatakan bahwa Model Interpersonal dapat menurunkan gejala depresi pada perempuan korban kekerasan rumah tangga, walaupun instrumen yang digunakan sama-sama menggunakan tes Beck Depression Inventory, kemungkinan perbedaan hasil antara kedua hasil penelitian disebabkan karena perbedaan populasi dan sampel yang digunakan.

Populasi dan sampel yang digunakan peneliti adalah lansia yang ada di Panti Sosial Tresna Werdha. Sedangkan pada penelitian sebelumnya yang dilakukan oleh Yudi Kurniawan menggunakan perempuan korban kekerasan rumah tangga untuk populasi dan sampelnya. Dari hasil penelitiannya di dapatkan Model 
Interpersonal merupakan terapi yang efektif untuk menangani kasus depresi klinis. Seperti yang dijelaskan Model Interpersonal berfokus untuk mengobati depresi dengan meningkatkan hubungan interpersonal yang bermasalah.

Begitu juga dengan faktor respondn yang terbatas, sehingga homogenitas responden yang dipakai masih kurang. Peneliti lebh memfokuskan pada hoogenits responden berdasarkan tingkat depresi. Sementara untuk faktor-faktor lain yang mempengaruhi depresi pada lansia seperti: frekuensi kunjungan keluarga, lama tinggal dipanti, pekerjaan sebelum masuk panti, motivasi masuk panti dan ada tidaknya keluhan penyakit tidak bisa dilakukan homogenitas[11]. Selain itu dari peneliti sendiri mengalami banyak keterbatasan dalam hal ketrampilan berkomunikasi dengan lansia. Semua hal diatas sejalan dengan pendapat yan menyatakan bahwa faktor responden dan peneliti akan mempengaruhi hasil penelitian yang di dapatkan[10].

Pada TAK Psikodrama, didapatkan nilai signifiknsi $\mathrm{p}=0,005$. ini menunjukkan besarnya pengaruh TAK Psikodrama dalam merubah tingkat depresi responden kearah yng lebih baik. yang berarti pula nilai keefektivitasannya dalam merubah tingkat depresi pada lansia di Panti Sosial Tresna Werdha Mataram cukup tinggi. Penggunaan TAK Psikodrama mampu memotivasi responden untuk menggali emosionalnya di masa lalu sebagai sumber depresi melalui peran yang di tampilkan. Keadaan ini menjadian TAK Psikodrama sebagai Life Review Terapy pada proses berpikir lansia yang telah mengalami penurunan kemampuan dalam mengingat jangka pendek dan mudah mengingat jangka panjang. Ini sesuai dengan pendapat Deborah-Otong [12] yang menyatakan bahwa cara yang terbaik dalam mengatasi depresi pada lansia adalah dengan life review terapy. Dengan mereview kembali pengalaman masa lalu yang membuat lansia depresi, dan dengan melakukan metode ekspresi perasaan melalui drama akan memicu munculnya rasa percaya diri dan perasaan dihargai pada lansia yang berdampak munculnya koping positif yang mempengaruhi persepsi dan emosi lansia dalam memandang suatu masalah[8]. Pri'e dalam Ilmi [13] mengatakan ketika mekanisme diri berhasil, kecemasan menurun dan rasa aman datang lagi.

Hasil penelitian ini didukung oleh penelitian yang dilakukan oleh Hendro Priono [8] yang menyimpulkan bahwa ada pengaruh TAK model psikodrama dalam merubah tingkat sters pada lansia di Panti Sosial Tresna Werdha Ilomata kota Gorontalo. Setelah pemberian TAK Psikodrama terjadi perubahan tingkat stres pada responden dengan tingkat kemaknaan $\mathrm{p}=0,005$ artinya ada pengaruh yang signifikan antara pemberian TAK Psikodrama dengan perubahan tingkat stres pada responden. Efek yang dirasakan para lansia setelah mengikuti psikodrama yaitu peserta menjadi lebih baik, memahami perasaan emosi dalam dirinya dan mampu memahami orang-orang di sekitar[14].

\section{KESIMPULAN}

TAK model Interpersonal tetap mampu memberikan perubahan pada tingkat depresi lansia di Panti Sosial Tresna Werdha Mataram, walaupun nilai keefektivitasannya masih kurang. TAK model Psikodrama memiliki nilai keefektivitasan yang lebih tinggi bila di bandingkan dengan TAK model Psikodrama dalam merubah tingkat depresi lansia di Panti Sosial Tresna Werdha Mataram. Keefektivitasan TAK model Interpersonal dan Psikodrama sangat dipengaruhi oleh homogenitas responden di Panti Sosial Tresna Werdha Mataram dan kemampuan peneliti.

\section{E. UCAPAN TERIMA KASIH}

Terimakasih kepada kepala Panti Sosial Tresna Werdha Mataram yang telah memberikan kesempatan untuk meneliti perubahan tingkat depresi pada lansia.

\section{DAFTAR PUSTAKA}

[1] Lubis N.L. 2016. Depresi Tinjauan Psikologi Edisi 2. Jakarta. Kencana 
[2] Kowel, R. 2016. Pengaruh Senam Lansia Terhadap Derajat Depresi Pada Lansia di Panti Werda. Thesis. Departemen fisiologi fakultas kedokteran universitas sam ratulangi

[3] Hawari, D. 2013. Stress, Cemas, dan Depresi. Jakarta : FK UI

[4] Parasari, G.A.T. 2015. Hubungan Dukungan Keluarga dengan tingkta depresi pada lansia di kelurahan sading. Program studi psikologi fakultas kedokteran universitas udayana

[5] Yusuf, A. 2017. Terapi Kognitif Menurunkan Tingkat Depresi Lansia (Cognitive Therapy Decrease the Level of Depression). Fakultas Keperawatan Universitas Airlangga Kampus C Mulyorejo Surabaya.

[6] Wahab, A.F. 2014. Pengaruh Aktivitas Kelompok (TAK) Terhadap Peningkatan Harga Diri Dan Motivasi Lansia. Thesis. Fakultas Kedokteran Program Pascasarjana Universitas Sebelas Maret Surakarta

[7] Purwaningsih. 2010. Asuhan Keperawatan Jiwa, Yogjakarta. Nuha Medika.

[8] Priyono, H. 2015. Pengaruh Terapi Aktivitas Kelompok Model Psikodrama Terhadap Peningkatan Perubahan Tingkat Kecemasan Lansia Di Panti Sosial Tresna Werdha Ilomata Kota Gorontalo. Program Studi Ilmu Keperawatan Fakultas Ilmu Kesehatan dan Keolahragaan Universitas Negeri Gorontalo.

[9] Kurniawan, Y. 2017. Psikoterapi Interpersonal untuk Menurunkan Gejala Depresi pada Perempuan Korban Kekerasan dalam Rumah Tangga. Program Studi Psikologi, Fakultas Psikologi, Universitas Semarang

[10] Nursalam. 2015. Metodelogi Penelitian Ilmu Keperawatan. Jakarta. Salemba Medika.

[11] Putri, S.M. 2016. Terapi Aktivitas Kelompok Orientasi Realita. Fakultas Keperawatan Universitas Andalas.

[12] Deborah-Otong, A. 2016. Psychiatric nursing : Biological \& Behavioral concept. Second Edition. Clifton Park, NY: Delmar Thomson Learning.

[13] Ilmi, N. 2012. Hubungan Persepsi Menopause dengan Kecemasan Menopause di Desa Sambibulu Kecamatan Taman Kabupaten Sidoarjo Jawa Timur. Jurnal.
Akademi Kebidanan Siti Khodijah Muhammadiyah Sepanjang-Sidoarjo

[14] Kusuma, P.J. 2018. Efektivitas Psikodrama Untuk Meningkatkan Empati Pada Saksi Mata Perundungan. Thesis. Program Studi Magister Psikologi Profesi Fakultas Psikologi Universitas Muhammadiyah Surakarta 